\title{
URGENSI LEGALITAS LEMBAGA KEUANGAN MIKRO SYARIAH
}

\author{
Dadan Muttaqien \\ Universitas Islam Indonesia \\ Email: dadanmuttaqien@yahoo.com
}

\section{Abstract}

Baitul Maal Wat Tamwil (BMT) is a customer self-help groups as an economic institution of the people who seek to develop productive enterprises and investment with the system of profit and loss sharing to enhance the quality of small economies. BMT combines two different activities in nature (profit and nonprofit) in one institution. BMT existence is expected to contribute significantly in developing a real economy sector, especially for business activities which do not meet all the requirements to obtain financing from the Islamic banking institution in general. Currently, BMT has triggered the development of small business better. The existence of BMT is helpful undercapitalized small businesses with financing facilities and financing facilities resulting in increased revenue. Behind this success BMT harbored a matter of emergency to get a solution. Therefore, in this paper, described how the operational $B M T$ and common constraints it faces, and most importantly is the solution to the fore. BMT as Islamic microfinance institutions have had time to improve itself to meet the needs of the community will fund the development of micro-enterprise activities. The presence of BMT is one contribution to the success of the development process, so that slowly but surely to erode or reduce the number of poor in Indonesia.

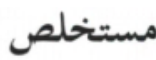

هذه المقالة باحثة عن دور بيت المال و التمويل(BMT) وهو كمؤستسة الاقتصادية الشرعية. كيف

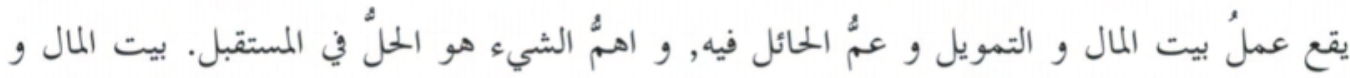

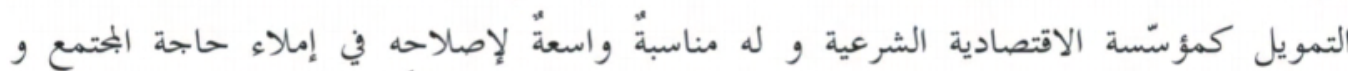

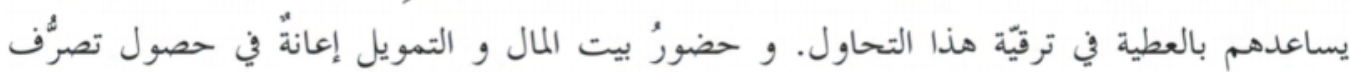
الترقيّة, و يُمكنه نقصُ جملة المساكين في إندونسيا خطوةً فخطوةً.

Keywords: BMT, legalitas, kendala dan solusi 


\section{A. Latar Belakang}

Dewasa ini fenomena penerapan prinsip syariah dalam lembaga keuangan semakin berkembang pesat, tidak hanya di perbankan tetapi juga lembaga keuangan bukan bank (LKBB). Di sektor lembaga keuangan bank dikenal dengan perbankan syariah, sedangkan pada lembaga keuangan bukan bank dengan mengacu pada Penjelasan Pasal 49 huruf i Undang Undang Nomor 3 Tahun 2006 tentang Perubahan Atas Undang-Undang Nomor 7 Tahun 1989 tentang Peradilan Agama, terdiri dari lembaga keuangan mikro syariah, asuransi syariah, reasuransi syariah, reksadana syariah, obligasi syariah dan surat berharga berjangka menengah syariah, sekuritas syariah, pembiayaan syariah, pegadaian syariah, dana pensiun lembaga keuangan syariah, dan bisnis syariah. ${ }^{2}$

Meskipun Indonesia terlambat dalam memulai praktek keuangan syariah namun perlahan tapi pasti Indonesia menunjukkan kinerja yang jauh lebih baik. Dalam industri perbankan syariah misalnya, secara kuantitatif maupun kualitatif, pertumbuhan di Indonesia saat ini lebih baik. Jumlah bank umum yang menawarkan layanan syariah di Indonesia melebihi Malaysia, apalagi bila dihitung jumlah BPR Syariah. Belum lagi bila jumlah BMT ikut diperhitungkan. Dari sisi kualititatif, persentase pembiayaan bermasalah-pun perbankan syariah Indonesia jauh lebih baik. ${ }^{3}$

Dalam perkembangan selanjutnya di Indonesia, didorong oleh rasa keprihatinan yang mendalam terhadap banyaknya masyarakat miskin yang terjerat oleh rentenir dan juga memberikan alternatif bagi mereka yang ingin mengembangkan usahanya, namun tidak dapat berhubungan secara langsung dengan perbankan Islam dikarenakan usahanya tergolong kecil dan mikro, maka pada tahun 1992 lahirlah sebuah lembaga keuangan kecil yang beroperasi dan menggunakan gabungan antara konsep Baitul Maal dan Baitut Tamwil yang target, sasaran, dan skalanya pada sektor usaha mikro. Lembaga tersebut "memberanikan diri" bernama Baitul Maal Wat Tamwil yang disingkat BMT. ${ }^{4}$

BMT ini masuk dalam istilah lembaga keuangan mikro syariah. Keberadaaan BMT di Indonesia ini diharapkan dapat memberikan kontribusi yang nyata dalam pengembagan sektor ekonomi riil, terlebih bagi kegiatan usaha yang belum memenuhi segala persyaratan untuk mendapatkan pembiayaan dari lembaga perbankan syariah. ${ }^{5}$ hal 15.

Muhammad, Manajemen Baitul Maal Wat Tamwil (BMT). Cet I. (Yogyakarta: STIS, 1998),

Aziz Budi Setiawan, Perbankan Syariah; Challenges dan Opportunity Untuk Pengembangan di Indonesia, dalam Jurnal Kordinat, Edisi: Vol.VIII No.1, April 2006.

4 Andriani, Baitul Maal Wat Tamwil (Konsep dan Mekanisme di Indonesia), dalam Jurnal Empirisma, Volume 14 No.2 Juli 2005, hal 251.

5 Hendi Suhendi, Strategi Optimalisasi Peran BMT Sebagai Penggerak Sektor Usaha Mikro. (Artikel). (Bandung: Fakultas Syari'ah dan Hukum UIN SGD Bandung, tt), hal 1. 
Harus diakui, bahwa dalam perkembangannya BMT yang terbilang belum lama ini telah mampu memberikan solusi positif terhadap pelaku usaha mikro. Penelitian Mochammad Nadjib Dkk (2006) tentang Pengaruh Baitul Maal Wat Tamwil Terhadap Kondisi Sosial Ekonomi Masyarakat, membuktikan bahwa sebagian besar responden sebelum menjadi nasabah BMT tidak memiliki sumber modal untuk membiayai usahanya, rata-rata mereka membiayai dari sumber pribadi dengan cara menyisihkan uang belanja atau menjual sebagian barang untuk modal. Meskipun demikian, sebagian responden yang mempunyai akses pada sumber modal waktu itu ada diantaranya yang terperangkap oleh bantuan modal yang berasal dari para pelepas uang (rentenir). Berdasarkan hasil wawancara dengan pihak pengelola BMT dan pengakuan responden diperoleh keterangan bahwa pihak pelepas uang dalam operasi usahanya membebankan bunga kepada peminjam bisa mencapai $5 \%$ per bulan. Setalah menjadi nasabah BMT, seluruh responden dapat dikatakan telah bebas dari pengaruh pelepas uang. Sebab salah satu syarat yang harus dipenuhi untuk mendapatkan pinjaman dari BMT adalah bahwa pengusaha tidak lagi ada kaitanya dengan para pelepas uang dan bagi pengusaha yang betul-betul kesulitan untuk melunasi pinjaman dari pelepas uang, maka BMT mempunyai kebijakan untuk membantu para calon nasabah dengan memberikan pinjaman dari bantuan qardul hasan yang merupakan pinjaman kebajikan tanpa bunga disamping sekaligus diberikan pinjaman yang bersifat komersial. ${ }^{6}$

\section{B. Persoalan Klasik BMT}

Keberadaan BMT sebagai lembaga keuangan mikro syariah sempat mengalami pasang dan surut. Pada pertengahan 1990-an di saat pemerintahan Presiden Suharto, jumlah BMT sempat disebutkan mencapai 3000 unit. Namun, pada bulan Desember 2005, jumlah BMT yang aktif dilaporkan tinggal 2.017 unit. Menurut Pusat Inkubasi Usaha Kecil (Pinbuk), sampai dengan pertengahan tahun 2006, jumlah BMT kembali bertambah menjadi sekitar 3.200 unit. (Susamto dan Cahyadin, 2008) Untuk tahun 2010, Pertumbuhan BMT diproyeksikan bisa tercapai 30-40\%. Selain itu, jumlah pemain di industri keuangan syariah mikro ini dipastikan bisa dicapai hingga kisaran 4.000 BMT. $^{7}$

6 Mochammad Nadjib, et al. 2006. Pengaruh Baitul Maal Wat Tamwil (BMT) terhadap Kondisi Sosial Ekonomi Masyarakat. Makalah disampaikan dalam Seminar Hasil-Hasil Penelitian P2E-LIPI, tanggal 11-12 Oktober 2006, hal 9.

7 Anonim, Pertumbuhan BMT Bakal Catat Rekor. Diakses pada 1 Juli 2010 dari http:// permodalanbmt.com, Posted on 15 Pebruari 2010. 
Dibalik perkembangan BMT secara nasional yang begitu cepat, BMT di Indonesia tidak terlepas dari kendala yang mereka hadapi. Di antaranya yang paling krusial adalah landasan hukum yang belum jelas.

BMT sebagai lembaga keuangan mikro bergerak dalam kegiatan usaha menghimpun dan menyalurkan dana dari masyarakat. Betapapun kegiatan penghimpunan dan penyaluran dana oleh BMT ini dalam skala kecil, namun kegiatan usaha ini secara yuridis tampak berlawanan dengan peraturan perundangundangan yang berlaku di bidang perbankan. Menurut pasal 16 ayat (1) Undang Undang Nomor 10 tahun 1998, kegiatan menghimpun dana dari masyarakat dalam bentuk simpanan hanya dapat dilakukan oleh Bank Umum atau BPR, kecuali apabila kegiatan itu diatur dengan undang-undang tersendiri. Ketentuan dalam pasal 16 ayat (1) tersebut dinyatakan sebagai berikut:

"Setiap pihak yang melakukan kegiatan menghimpun dana dari masyarakat dalam bentuk simpanan wajib terlebih dahulu memperoleh izin usaha sebagai Bank Umum atau Bank Perkreditan Rakyat dari Bank Indonesia, kecuali apabila kegiatan menghimpun dana dari masyarakat dimaksud diatur dengan undangundang tersendiri."

Larangan sebagaimana tersebut pada pasal 16 disertai dengan ancaman sanksi pidana, yang tercantum dalam pasal 46 ayat (1) Undang Undang Nomor 10 tahun 1998 sebagai berikut:

"Barang siapa menghimpun dana dalam bentuk simpanan tanpa izin usaha dari Pimpinan Bank Indonesia sebagaimana dimaksud dalam pasal 16, diancam dengan pidana penjara sekurang-kurangnya 5 (lima) tahun dan paling lama 15 (lima belas) tahun serta denda sekurang-kurangnya Rp. 10.000.000.000,00 (sepuluh miliar rupiah) dan paling banyak Rp. 200.000.000.000,00 (dua ratus miliar rupiah)”

Berdasarkan ketentuan undang-undang tersebut di atas maka terdapat permasalahan hukum di dalam BMT. Di satu sisi Undang Undang Perbankan melarang dan memberikan ancaman sanksi, dan di sisi lain BMT belum memiliki landasan peraturan perundangan selain dukungan politis dari pemerintah.

Untuk mengatasi krisis hukum tersebut maka di dalam prakteknya sebagian BMT mengambil bentuk badan usaha koperasi dan sebagian lain belum memiliki badan usaha yang jelas atau masih bersifat pra-koperasi. ${ }^{8}$ Koperasi merupakan bentuk badan usaha yang relatif lebih dekat untuk BMT, tetapi menurut Undang Undang Perkoperasian kegiatan menghimpun dana simpanan terbatas hanya dari para

8 Muhammad, Lembaga-lembaga Keuangan Umat Kontemporer, (Yogyakarta: UII Press, 2000), hal 144. 
anggotanya (Pasal 44 UU. No. 25/ 1992). Pasal 44 ayat (1) U.U. No. 25 Tahun 1992 selengkapnya mengatur sebagai berikut: "Koperasi dapat menghimpun dana dan menyalurkannya melalui kegiatan usaha simpan pinjam dari dan untuk: (a) Anggota Koperasi yang bersangkutan; (b) Koperasi lain dan/atau anggotanya."

Alhasil, BMT mau tidak mau harus mensyaratkan keanggotaan bagi nasabah yang akan dilayani, atau menjadikan nasabah tersebut sebagai calon anggota selama beberapa waktu tertentu. Konsekuensinya, tidak saja sebagian calon nasabah menjadi enggan, tetapi juga menyebabkan masalah internal di dalam BMT, karena setiap anggota -baik yang lama, maupun yang sama sekali baru dan tidak memahamai visi BMT- mempunyai hak suara yang sama. Sementara, bila BMT ingin dapat menghimpun dana dari masyarakat langsung, maka BMT harus berganti status hukum menjadi bank atau lembaga keuangan bukan bank, seperti modal ventura. Sehingga BMT justru akan kehilangan kelebihan utama mereka sebagai lembaga keuangan yang melayani usaha berskala mikro. ${ }^{10}$

Oleh sebab itu meskipun BMT telah berbadan hukum koperasi namun hal itu belum sepenuhnya sesuai dengan kegiatan usaha BMT yang sebagian besar dananya berasal dari simpanan masyarakat berdasarkan prinsip syariah. Sistem kegiatan penghimpunan dana dari masyarakat itu menyebabkan kedudukan dan operasional BMT, baik BMT pra-koperasi maupun koperasi, masih merupakan permasalahan yang menimbulkan kerancuan atau kekaburan batas perbedaan antara operasional BMT sebagai koperasi dengan BMT sebagai bank.

Kedudukan hukum dan operasional BMT merupakan persoalan yang dilematis bagi BMT. Satu sisi dengan adanya kekosongan aturan hukum itu merupakan "keleluasaan gerak" bagi BMT yang memungkinkan tumbuh dari bawah dengan pesat, namun di sisi lain kegiatan usaha BMT yang belum memiliki dasar hukum tersebut telah menimbulkan permasalahan-permasalahan tentang kepastian hukum. ${ }^{11}$

Selain persoalan legalitas diatas, Jika dipetakan, kendala-kendala yang menjadi hambatan pengelolaan BMT dalam pemberdayaan sektor riil dapat dibedakan menjadi dua macam, yaitu kendala internal dan kendala eksternal.

9 Muhammad Muhtarom, Aspek Hukum Lembaga Keuangan Baitul Mal Wa Tamwil (Bmt), diakses pada 23 Oktober 2010. dari http://muhtarom-enterprisenet.blogspot.com

10 Akhmad Akbar Susamto dan Malik Cahyadin, Praktik Ekonomi Islami Di Indonesia Dan Implikasinya Terhadap Perekonomian. Dalam Jurnal Ekonomi Syariah MUAMALAH, vol 5, tahun 2008. Lihat juga Nadjib, Mochammad. et al. 2006. Pengaruh Baitul Maal Wat Tamwil (BMT) terhadap Kondisi Sosial Ekonomi Masyarakat. Makalah disampaikan dalam Seminar Hasil-Hasil Penelitian P2E-LIPI, tanggal 11-12 Oktober 2006, hal 18.

11 Muhammad Muhtarom, Aspek Hukum Lembaga Keuangan Baitul Mal Wa Tamwil (BMT), diakses pada 23 Oktober 2010. dari http://muhtarom-enterprisenet.blogspot.com 
a. Kendala internal adalah kendala yang disebabkan karena faktor dari dalam BMT itu sendiri. Hal ini nampak pada adanya fakta bahwa banyak dijumpai pengurus atau pengelola BMT belum memahami tentang prinsip-prinsip syariah dan juga prinsip pengelolaan usaha yang baik dan benar. Atau dengan kata lain belum terpenuhinya sumber daya insani yang mumpuni di bidang ekonomi syariah, sehingga dalam praktiknya BMT seringkali menjadi sama dengan lembaga keuangan konvensional yang jauh dari nilai-nilai Islami.

b. Kendala eksternal adalah kendala yang disebabkan oleh faktor dari luar BMT, seperti masih adanya budaya masyarakat yang belum sepenuhnya menerima eksistensi lembaga keuangan syariah karena di anggap njlimet dan tidak terprediksi. Kendala pada aspek hukum juga masih dijumpai, yakni terkait dengan status hukum BMT yang pada umumnya adalah koperasi. Menurut ketentuan hukum koperasi memerlukan aspek legal lain jika ingin melakukan kegiatan penghimpunan dana. Fungsi BMT yang hampir mirip-mirip dengan bank, yakni sebagai lembaga intermediasi keuangan belum mendapatkan pijakan hukumnya yang kokoh. ${ }^{12}$

Sudah barang tentu kendala-kendala diatas membawa dampak yang cukup serius bagi perkembangan BMT secara umum, muncul pesoalan-persoalan baru yang mencederai idealisme dunia per-BMT-an. Media masa banyak menulis, bahwa banyak terjadi penyelewengan pengumpulan dana masyarakat yang mengatas namakan BMT. Banyak modus yang dilakukan oleh segelintir orang dalam melakukan penyelewengan tersebut. Mulai dari penipuan secara terang-terangan hingga penipuan dengan cara tersembunyi dengan iming-iming "bagi hasil" yang sangat tidak rasional. Nama "BMT" mereka gunakan semata-mata karena mereka melihat bahwa nama ini identik dengan idiom keagamaan yang sangat mudah untuk menyentuh emosi masyarakat, sehingga masyarakat menaruh kepercayaan yang tinggi, bahkan mempunyai espektasi yang tinggi pula dan mereka percaya terhadap janji-janji muluk.

Fenomena seperti ini tidak saja merugikan masyakarat yang menjadi korban penipuan, namun juga memunculkan stigma negatif terhadap BMT pada umumnya. Bahkan lebih jauh, karena BMT diinisiasi berangkat dari nilai-nilai moral keagamaan, maka stigma negatif tehadap agamapun tidak bisa dihindari. Islam terdegradasai nilai-nilai luhurnya akibat prilaku yang sebenarnya jauh dari nilai-nilai Islam itu

12 Hendi Suhendi, Strategi Optimalisasi Peran BMT Sebagai Penggerak Sektor Usaha Mikro. (Artikel). (Bandung: Fakultas Syari'ah dan Hukum UIN Sunan Gunung Djati), hal 7. 
sendiri. Kondisi ini diperparah oleh pemahaman masyarakat yang belum tuntas terhadap konsep dasar yang mejadi basis epistemologis BMT ini. Sehingga masyarakatpun terjebak pada sikap stereotipe terhadap keberadaan BMT, dan BMT pun menjadi "babak belur" karena prilaku menyimpang ini. ${ }^{13}$ Untuk itulah sudah semestinya, jika para pelaku dan pemerhati BMT segera mengambil langkah produktif untuk menghentikan praktek-praktek menyimpang yang mengatasnamakan BMT. ${ }^{14}$

Dari sekian persoalan dan kendala diatas yang selalu menjadi perhatian para pemerhati dan peneliti ekonomi syariah adalah masih banyak yang mempersoalkan kelembagaan BMT secara internal dan eksternal sejak 1992 hingga kini yang tak kunjung ada jalan keluar, sehingga secara kelembagaan BMT menjadi lembaga keuangan "syariah liar".

\section{Perlu Perbaikan Terencana}

Berangkat dari beberapa kajian hasil penelitian khususnya dari sudut pandang anggota BMT atau nasabah BMT, diantaranya Penelitian Evy Meirina Budi Astuti (2007), tentang Evaluasi Tingkat Pendapatan Usaha Kecil Sebelum dan Sesudah Memperoleh Pembiayaan dari BMT Beringharjo, Kauman, Yogyakarta. Penelitian ini menemukan bahwa keberadaan BMT Beringharjo Kauman sangat membantu usaha kecil yang kekurangan modal dengan pembiayaan yang diberikan dan pembiayaan yang diberikan berujung pada peningkatan pendapatan. ${ }^{15}$

Penelitian Prasetyo Adi (2008), Tentang Analisis Pengaruh Kualitas Pelayanan Terhadap Kepuasan Nasabah BMT Kaffah Yogyakarta, berusaha untuk mengetahui pengaruh kualitas pelayanan terhadap tingkat kepuasan nasabah BMT Kaffah Yogyakarta. Hasilnya, dimensi kualitas pelayanan yang terdiri dari Responsivness, Reliability, Assurance, Emphaty dan Tangibles berpengaruh

13 Temuan M. Roem Syibly. 2008 terhadap pengusaha NU, bahwa semakin tinggi pendidikan pengusaha NU maka semakin tidak percaya terhadap perbankan syariah. Selain itu, mereka menilai bahwa bank syariah adalah rentenir berganti baju. Lebih detail lihat M. Roem Syibly. 2008. Preferensi Pengusaha NU terhadap Bank Syariah (Studi Kasus Anggota Pengajian Bisnis al-Kautsar PW NU Yogjakarta). Tesis. Yogyakarta: UIN Sunan Kalijaga Yogyakarta.

14 Yazid Afandi, Religiousity Value dalam Pengelolaan BMT, diakses pada 12 Januari 2011, dari http://yazidafandi. wordpress.com

15 Evy Meirina Budi Astuti, Evaluasi Tingkat Pendapatan Usaha Kecil sebelum Dan Sesudah Memperoleh Pembiayaan Dari Bmt Beringharjo, Kauman, Yogyakarta. Skripsi. (Yogyakarta: FEUII, 2007). 
positif terhadap kepuasan nasabah. ${ }^{16}$ Temuan ini diteruskan oleh Penelitian Tuti Supriyatmini (2005) tentang Pengaruh Persepsi Nasabah Tentang Kualitas Pelayanan Terhadap Loyalitas Nasabah Pada Baitul Maal Wattamwil (BMT) “Anda” Semarang, menemukan bahwa ada pengaruh antara kualitas pelayanan terhadap loyalitas nasabah. ${ }^{17} \mathrm{Hal}$ yang sama ditemukan oleh Penelitian Wahyuni, Sri (2007) tentang Analisis Pengaruh Kualitas Pelayanan Jasa Terhadap Kepuasan Nasabah BMT Amanah Ummah Cabang UMS, ditemukan bahwa variabel reliability, responsiveness, assurance, emphaty dan tangible secara parsial mempunyai pengaruh yang signifikan terhadap kepuasan nasabah BMT Amanah Ummah UMS. ${ }^{18}$

Persolan BMT dapat dilihat dari Penelitian Nur Azizah (tt), Evaluasi Penerapan Prinsip Syariah Pada Praktik Pembiayaan Mudharabah atau Revenue Sharing (Studi Kasus di KJKS BMT Nuur Ummah Surakarta, menemukan kelemahan seperti: (1) Besar nisbah bagi hasil yang terlalu besar memberatkan mudharib yang mempunyai pendapatan kecil. (2) Margin yang telah ditentukan tidak selalu diberitahukan kepada mudharib. (3) Dalam penyelesaian sengketa dilakukan penyitaan secara paksa. ${ }^{19}$

Dari beberapa kajian penelitian-penelitian diatas terlihat bahwa BMT secara umum diterima oleh masyarakat dengan meningkatnya pendapatan hasil usaha dan faktor pelayanan menjadi kunci keberhasilan. Tetapi meninggalkan masalah substansi BMT itu sendiri, sehingga penelitian azizah diatas harus menjadi perhatian serius bagi pengelola BMT secara umum. Penelitian Azizah diatas berakibat pada menurunnya kepercayaan jangka panjang masyarakat terhadap BMT, sehingga wajar bila kemudian beberapa kalangan pelaku usaha cukup sinis memandang perbankan syariah secara umum. Lihat saja penelitian Syibly (2008), bahwa semakin tinggi tingkat pendidikan pelaku usaha maka semakin tidak percaya dengan perbankan syariah dan lebih memilih perbankan konvensional dan semakin besar modal yang

16 Prasetyo Adi, Analisis Pengaruh Kualitas Pelayanan Terhadap Kepuasan Nasabah BMT Kaffah Yogyakarta, Skripsi, (Yogyakarta: Jurusan Ekonomi Islam STAIN Surakarta -SEM Institute Yogyakarta, 2008).

17 Tuti Supriyatmini, Pengaruh Persepsi Nasabah Tentang Kualitas Pelayanan Terhadap Loyalitas Nasabah Pada Baitul Maal Wattamwil (BMT) "Anda” Semarang, Skripsi, (Semarang: Jurusan Pendidikan Ekonomi Koperasi, FIS-UNESA, 2005).

18 Sri Wahyuni, Analisis Pengaruh Kualitas Pelayanan Jasa Terhadap Kepuasan Nasabah BMT Amanah Ummah Cabang UMS, Skripsi, (Surakarta: Universitas Muhammadiyah Surakarta, 2007).

19 Nur Azizah, Evaluasi penerapan prinsip syariah pada praktik pembiayaan mudharabah atau revenue sharing, (studi kasus di KJKS BMT Nuur Ummah Surakarta), (Surakarta: UNS, tt) 
dimiliki pengusaha maka semakin memilih perbankan konvensional sebagai referensinya. Yang mengejutkan lagi bahwa para pelaku usaha ini memandang perbankan syariah sama halnya rentenir berganti baju. ${ }^{20}$

Kami melihat bahwa bila demikian adanya, maka BMT atau bahkan lembaga keuangan syariah secara umum yang tumbuh subur ini hanya booming sementara saja dan akan tergantikan dengan model lembaga keuangan lain yang mungkin dapat memberikan "kepuasan" nasabah lebih baik bila tidak secara terencana ada perbaikan yang lebih baik.

\section{Beberapa alternatif solusi}

1. Menyempurnakan peraturan perundang-undangan yang dapat mengakomodir program BMT, agar BMT dapat mengembangkan usahanya dengan lebih mudah dan tidak ragu-ragu lagi untuk mensinergikan produk-produknya dengan yang lain.

2. Perbaikan SDM. SDM yang profesional merupakan syarat mutlak dan keharusan dalam mengelola usaha. Selain itu, SDM lembaga syariah ini juga dituntut untuk berkemampuan teknis (skill) perbankan, guna memahami ketentuan dan prinsip syariah, selain memiliki akhlak dan moral yang islami. ${ }^{21}$

3. Sosialisai hendaknya dilakukan tiada henti dan optimalisasi peran-peran komite pengarah, komite ahli dan komite kerja secara intensif. ${ }^{22}$

4. Memiliki standarisasi manajemen, administrasi, laporan keuangan syariah. Serta menerapkan prinsip-prinsip Good Corporate Governance, yang meliputi transparancy, accountability, responsibility, independency, and fairness.

5. Perlunya menghadirkan lembaga penjamin likuiditas BMT. Kebutuhan lembaga penjamin likuiditas ini menjadi penting mengingat banyaknya BMT yang berhasil mengumpulkan dana masyarakat dalam jumlah yang cukup besar

20 Lihat M. Roem Syibly, Preferensi Pengusaha NU terhadap Bank Syariah (Studi Kasus Anggota Pengajian Bisnis al-Kautsar PW NU Yogjakarta), Tesis, (Yogyakarta: UIN Sunan Kalijaga, 2008).

${ }_{21}$ Banyak dijumpai pengurus atau pengelola BMT belum memahami tentang prinsip-prinsip syariah dan juga prinsip pengelolaan usaha yang baik dan benar. Atau dengan kata lain belum terpenuhinya sumber daya insani yang mumpuni di bidang ekonomi syariah, sehingga dalam praktiknya BMT seringkali menjadi sama dengan lembaga keuangan konvensional yang jauh dari nilai-nilai Islami. lihat paper Hendi Suhendi Strategi Optimalisasi Peran BMT Sebagai Penggerak Sektor Usaha Mikro. Paper. Bandung: Fakultas Syariah dan Hukum UIN SGD

22 Zarida. Pemberdayaan usaha Kecil Menengah Model BMT (bagian VI) dalam Darwin (ed), Model-model pemberdayaan usaha kecil dan menengah, (Jakarta: Pusat Penelitian Ekonomi, Lembaga Ilmu Pengetahuan Indonesia. 2003).hal 188. 
sementara perangkat lembaga yang menjamin keamanan dana masyarakat tersebut belum ada. ${ }^{23}$

6. Penggunaan Teknologi. Tidak dapat dipungkiri bahwa keberhasilan suatu usaha juga ditentukan oleh teknologi khususnya teknologi informasi, informasi terkini menjadi sangat penting dalam pengembangan usaha dan persaingan pasar. ${ }^{24}$ Dengan demikian, mengacu pada prinsip perbankan syariah, maka BMT seyogyanya memiliki karakteristik sebagai berikut:

1. Tidak mengarah pada pola pelayanan keuangan perbankan konvensional, terutama dalam hal.

a. Tetap mempertahankan prinsip perbankan syariah dalam operasionalnya dengan menjaga sistem bagi hasil yang tidak mengarah pada sistem bunga; ${ }^{25}$

b. dalam hal persyaratan tidak mensyaratkan kolateral dan tidak terdapat proses administratif formal yang menyulitkan;

2. Sasarannya adalah masyarakat miskin dan pengusaha mikro, di mana jasa keuangan yang diberikan dapat disesuaikan dengan karakteristik kelompok sasaran tersebut.

3. Menggunakan pendekatan kelompok, baik dengan ataupun tidak dengan sistem tanggung renteng yang mengedepankan pola hubungan kenal dekat sebagai landasan utama mengelola risiko.

4. Lingkup kegiatan BMT dapat mencakup pembiayaan kegiatan ekonomi produktif maupun konsumtif, pendampingan dan pendidikan, kegiatan penghimpunan dan bentuk kegiatan lain yang dibutuhkan oleh pengusaha mikro dan masyarakat miskin. ${ }^{26}$

\section{E. Penutup}

BMT sebagai lembaga keuangan mikro syariah sudah saatnya harus berbenah diri untuk memenuhi kebutuhan masyarakat akan dana bagi pengembangan kegiatan usaha mikro. Keberadaan BMT merupakan salah satu kontribusi bagi suksesnya

23 Chuzaimah Batubara, at al. Baitul Mal Wat Tamwil (BMT) Versus Rentenir (Studi BMT Kube Sejahtera, Sumatera Utara), diakses pada 20 Mei 2009, dari http://chuzaimahbb.multiply.com

24 Zarida. Pemberdayaan usaha Kecil Menengah Model BMT (bagian VI) dalam Darwin (ed), Model-model pemberdayaan usaha kecil dan menengah, (Jakarta: Pusat Penelitian Ekonomi, Lembaga Ilmu Pengetahuan Indonesia. 2003).hal 188.

25 Hasil penelitian Nadjib Dkk juga menemukan bahwa biaya operasional BMT relatif tinggi, penentuan profit rate masih dalam bayang-bayang interest rat, sistem pengupahan yang belum islami dan masih tercampurnya sumber pendanaan dengan unsur riba. (Mochammad Nadjib. et al, 2006: 18)

26 Chuzaimah Batubara, at al. Baitul Mal Wat Tamwil (BMT) Versus Rentenir (Studi BMT Kube Sejahtera, Sumatera Utara), diakses pada 20 Mei 2009, dari http://chuzaimahbb.multiply.com 
proses pembangunan, sehingga pelan tapi pasti dapat mengikis atau mengurangi jumlah penduduk miskin di Indonesia.

Masyarakat disarankan untuk hati-hati dengan cukup banyaknya BMT Palsu, BMT-BMT yang hanya sekedar mencari keuntungan belaka yang jauh dari prinsip syariah, Pengelolaan Baitul maal wat tamwil yang dalam praktiknya merugikan masyarakat perlu segera ditindak tegas. Masyarakat yang mengharapkan adanya Lembaga Keuangan Syariah (LKS), praktik semacam itu merugikan dan merusak citra BMT yang telah tumbuh dan berkembang dengan baik. ${ }^{27}$

Maraknya BMT yang tumbuh subur di masyarakat harus menjadi perhatian pemerintah agar segera memiliki kepastian hukum secara mandiri dan berujung pada kesejahteraan dan kemajuan ekonomi masyarakat kecil.

\section{DAFTAR PUSTAKA}

Adi, Prasetyo. 2008. Analisis Pengaruh Kualitas Pelayanan Terhadap Kepuasan Nasabah BMT Kaffah Yogyakarta. Skripsi. Yogyakarta: Jurusan Ekonomi Islam STAIN Surakarta -SEM Institute Yogyakarta

Afandi, Yazid, Religiousity Value dalam Pengelolaan BMT, diakses pada 12 Januari 2011, dari http://yazidafandi. wordpress.com

Andriani. 2005. Baitul Maal Wat Tamwil (Konsep dan Mekanisme di Indonesia). Dalam Jurnal Empirisma, Volume 14 No.2 Juli 2005.

Anonim. tt. Pertumbuhan BMT Bakal Catat Rekor. Diakses pada 1 Juli 2010 dari http://permodalanbmt.com, Posted on 15 Pebruari 2010.

Astuti, Evy Meirina Budi. 2007. Evaluasi Tingkat Pendapatan Usaha Kecil sebelum Dan Sesudah Memperoleh Pembiayaan Dari Bmt Beringharjo, Kauman, Yogyakarta. Skripsi. Yogyakarta: FE-UII.

Azizah, Nur. tt. Evaluasi penerapan prinsip syariah pada praktik pembiayaan mudharabah atau revenue sharing. (studi kasus di KJKS BMT Nuur Ummah Surakarta). Surakarta: UNS.

Batubara, Chuzaimah. at al. 2008. Baitul Mal Wat Tamwil (BMT) Versus Rentenir (Studi BMT Kube Sejahtera, Sumatera Utara). diakses pada 20 Mei 2009. Dari http://chuzaimahbb.multiply.com

27 Lihat Kompas, 8 Mei 2009. 
Harian Kompas, 8 Mei 2009

Muhammad. 1998. Manajemen Baitul Maal Wat Tamwil (BMT). Cet I. Yogyakarta: STIS. 2000. Lembaga-lembaga Keuangan Umat Kontemporer. Yogyakarta: UII Press.

Muhtarom, Muhammad. 2009. Aspek Hukum Lembaga Keuangan Baitul Mal Wa Tamwil (Bmt), diakses pada 23 Oktober 2010. dari http://muhtaromenterprisenet.blogspot.com

Nadjib, Mochammad. et al. 2006. Pengaruh Baitul Maal Wat Tamwil (BMT) terhadap Kondisi Sosial Ekonomi Masyarakat. Makalah disampaikan dalam Seminar Hasil-Hasil Penelitian P2E-LIPI, tanggal 11-12 Oktober 2006.

Nursali, dkk. 2004. Strategi Pengembangan Baitul Maal Wa Tamwil(BMT) dalam Memberdayakan Potensi Usaha Kecil dan Menengah sebagai Lembaga Keuangan Mikro Syariah. Karya Tulis. Malang: Universitas Brawijaya.

Setiawan, Aziz Budi. 2006. Perbankan Syariah; Challenges dan Opportunity Untuk Pengembangan di Indonesia, Jurnal Kordinat, Edisi: Vol.VIII No.1, April 2006.

Suhendi, Hendi. tt. Strategi Optimalisasi Peran BMT Sebagai Penggerak Sektor Usaha Mikro. (Artikel). Bandung: Fakultas Syari’ah dan Hukum UIN SGD Bandung.

Supriyatmini, Tuti. 2005. Pengaruh Persepsi Nasabah Tentang Kualitas Pelayanan Terhadap Loyalitas Nasabah Pada Baitul Maal Wattamwil (BMT) "Anda” Semarang. Skripsi. Semarang: Jurusan Pendidikan Ekonomi Koperasi, FISUNESA.

Susamto, Akhmad Akbar dan Malik Cahyadin. 2008. Praktik Ekonomi Islami Di Indonesia Dan Implikasinya Terhadap Perekonomian. Dalam Jurnal Ekonomi Syariah MUAMALAH vol 5, tahun 2008.

Syibly, M. Roem. 2008. Preferensi Pengusaha NU terhadap Bank Syariah (Studi Kasus Anggota Pengajian Bisnis al-Kautsar PW NU Yogjakarta). Tesis. Yogyakarta: UIN Sunan Kalijaga Yogyakarta.

Umar, Husain. 2000. Riset Pemasaran Dan Perilaku Konsumen. Jakarta: Gramedia Pustaka Utama. 
Wahyuni, Sri. 2007. Analisis Pengaruh Kualitas Pelayanan Jasa Terhadap Kepuasan Nasabah BMT Amanah Ummah Cabang UMS. Skripsi. Surakarta: Universitas Muhammadiyah Surakarta.

Zarida. 2003. Pemberdayaan usaha Kecil Menengah Model BMT(bagian VI) dalam Darwin (ed), Model-model pemberdayaan usaha kecil dan menengah, (Jakarta: Pusat Penelitian Ekonomi, Lembaga Ilmu Pengetahuan Indonesia). 